\title{
Pembelajaran Tematik di Sekolah Dasar dalam Pandangan Teori Konstruktivisme Vygotsky
}

\author{
Listiana Dewi $^{1 \bowtie}$ \& Endang Fauziati ${ }^{2}$
}

Universitas Muhammadiyah Surakarta, Indonesia

E-mail: ristiana68@gmail.com

\begin{abstract}
Abstrak
Tujuan dari penelitian ini adalah untuk mendeskripsikan pelaksanaan dan model pembelajaran tematik di Sekolah Dasar dalam pandangan teori Konstruktivisme Vygotsky. Jenis Penelitian yang digunakan dalam penelitian ini yakni penelitian kualitatif, dengan metode deskriptif. Penelitian ini juga merujuk pada model studi kepustakaan (library research) yang mana objek yang di kaji pada penelitian ini berasal dari buku, catatan, Jurnal, transkrip, laporan penelitian dan dokumen lain yang dapat ditemukan dan terkait dengan teori belajar Konstruktivisme Vygotsky dan pembelajaran tematik. Hasil penelitian menunjukkan bahwa pelaksanaan pembelajaran tematik di Sekolah Dasar dalam pandangan teori Konstruktivisme Vygotsky adalah melalui pendekatan scientific yang dilakukan melalui proses mengamati, menanya, mencoba, menalar, dan mengkomunikasikan. Model yang digunakan adalah model Pembelajaran Berbasis Masalah (Problem Based Learning), model Pembelajaran Berbasis Projek (Project Based Learning), dan model Pembelajaran Melalui Penyingkapan/Penemuan (Discovery/Inquiry Learning). Pembelajaran tematik lebih menghendaki peserta didik untuk bertukar fikiran atau diskusi dengan teman sebaya maupun orang yang lebih mampu untuk berkonsultasi, hal ini sesuai dengan implikasi teori belajar Konstruktivisme Vygotsky yang menghendaki pembelajaran yang menempatkan pembelajaran berorientasi pada student center.
\end{abstract}

Kata Kunci: Pembelajaran Tematik; Teori Konstruktivisme; Vygotsky

\begin{abstract}
The purpose of this study is to describe the implementation and thematic learning models in elementary schools in the view of Vygotsky's constructivism theory. The type of research used in this research is qualitative research, with descriptive-critical method. This research also refers to the library research model in which the objects studied in this study come from books, notes, journals, transcripts, research reports and other documents that can be found and related to Vygotsky's constructivism learning theory and thematic learning. The results showed that the implementation of thematic learning in elementary schools in the view of Vygotsky's constructivism theory was through a scientific approach which was carried out through the process of observing, asking, trying, reasoning, and communicating. The models used are the Problem Based Learning model, the Project Based Learning model, and the Discovery/Inquiry Learning model. Thematic learning requires students to exchange ideas or discussions with peers and people who are more able to consult, this is in accordance with the implications of Vygotsky's constructivism learning theory which requires learning that places learning oriented to the student center.
\end{abstract}

Keywords: Thematic Learning; Constructivism Theory; Vygotsky 


\section{PENDAHULUAN}

Pendidikan karakter sangat penting bagi pembentukan karakter yang kuat. Kegiatan belajar mengajar yang hanya memfokuskan pada kegiatan yang menekankan pada aspek kognitif saja maka karakter yang kuat tidak akan terbentuk. Melihat nilai strategis pendidikan, pemerintah melalui Departemen Pendidikan Nasional (Depdiknas) terus menerus melakukan berbagai perbaikan dan pembaharuan sistem pendidikan dengan harapan agar generasi bangsa Indonesia menjadi bangsa yang cerdas sekaligus berkarakter. Salah satu upaya pemerintah dalam melakukan berbagai perbaikan dan pembaharuan dalam sistem pendidikan nasional di Indonesia adalah dengan melakukan perubahan kurikulum. Pemerintah Indonesia berusaha mewujudkan tujuan pendidikan dengan memperbaiki sistem pendidikan dengan cara memberlakukan kurikulum 2013.

Model pembelajaran tematik merupakan perwujudan kurikulum 2013. Menurut (Drake, 2012:273), Pendekatan tematik merupakan bentuk strategi pembelajaran yang menggunakan tema melalui penciptaan pembelajaran yang aktif, menarik, dan bermakna. Dikatakan bermakna karena peserta didik diharapkan dapat memahami konsep-konsep melalui pengalaman langsung dan nyata yang menghubungkan antar konsep. Melalui kurikulum 2013, peserta didik didorong menjadi insan yang kreatif, produktif, inovatif, dan afektif melalui kompetensikompetensi yang berimbang antara spiritual, pengetahuan, sikap,

dan psikomotor/keterampilan (Kemdikbud (2013): 4).

Pendekatan yang digunakan dalam kurikulum 2013 adalah scientific.
Pendekatan scientific dalam kurikulum 2013 lebih dikenal dengan pendekatan ilmiah. Pendekatan scientific lebih mengedepankan penalaran secara induktif daripada deduktif. Penalaran induktif fenomena atau situasi spesifik kemudian menarik kesimpulan secara keseluruhan (Authentic \& Sekolah, 2013)

(Apriani, Wangid, \& Yogyakarta, 2015) mengemukakan bahwa pembelajaran tematik baik untuk dilaksanakan karena mampu meningkatkan soft skill dan hard skill peserta didik berdasar pada proses pembelajarannya yang aktif, menarik, dan bermakna. Pendidikan karakter sangat penting bagi pembentukan karakter yang kuat. Jika dalam proses belajar mengajar hanya memfokuskan pada kegiatan yang menekankan pada aspek kognitif saja maka karakter yang kuat tidak akan terbentuk. Hal ini dikuatkan dengan pendapat yang diungkapkan oleh (Saptono,2011:16) yang menyatakan bahwa pendidikan karakter sangat penting, karakter lebih tinggi nilainya daripada intelektualitas.

Model pembelajaran tematik menggunakan pendekatan scientific yang memberikan kesempatan peserta didik untuk dapat melakukan proses ilmiah yaitu mengamati, menanya, menalar, mencoba, dan mengkomunikasikan. Hal ini sesuai dengan teori belajar konstruktivisme Vygotsky yang lebih menitikberatkan interaksi dari faktor-faktor interpersonal (sosial), kultural-historis, dan individual sebagai kunci dari perkembangan manusia (Schunk, 2012: 339). Teori belajar ini berfokus pada peserta didik (student Centre). Guru berperan sebagai fasilitator.

Berdasarkan hal diatas, maka peneliti bermaksud untuk mengkaji lebih dalam mengenai mengenai pelaksanaan dan metode pembelajaran tematik di Sekolah Dasar 
dalam pandangan teori Konstruktivisme Vygotsky.

\section{METODE PENELITIAN}

Jenis Penelitian yang digunakan dalam penelitian ini yakni penelitian kualitatif, dengan metode deskriptif. Metode deskriptif kritis merupakan metode yang lebih menekankan pada kekuatan analisis data yang diperoleh melalui berbagai sumber-sumber yang diperoleh dari berbagai buku dan tulisan-tulisan lainnya dengan mengandalkan teori-teori yang ada untuk diinterpretasikan secara jelas dan mendalam untuk menghasilkan tesis dan anti tesis (Abdurrahman \& Soerjono, 1999).

Penelitian ini juga merujuk pada model studi kepustakaan (library research) yang mana objek yang di kaji pada penelitian ini berasal dari buku, catatan, Jurnal, transkrip, laporan penelitian dan dokumen lain yang dapat ditemukan dan terkait dengan teori belajar Konstruktivisme Vygotsky dan pembelajaran tematik.

Pada penelitian ini teknik yang digunakan untuk mengumpulkan data yakni dengan dokumentasi, pada teknik tersebut peneliti mengidentifikasi wacana dari buku-buku, makalah atau artikel, majalah, jurnal, web (internet), ataupun informasi lainnya yang berhubungan dengan teori belajar Konstruktivisme Vygotsky dan pembelajaran tematik ataupun yang berkaitan secara langsung dengan judul penulisan, setelah data terkumpul maka data tersebut dianalisis untuk mendapatkan konklusi, bentuk-bentuk dalam teknik analisis deskriptif.

\section{HASIL DAN PEMBAHASAN}

\section{Teori Konstruktivisme Vygotsky}

Teori Vygotsky lebih menitikberatkan interaksi dari faktor-faktor interpersonal (sosial), kultural-historis, dan individual sebagai kunci dari perkembangan manusia (Schunk, 2012: 339). Pusat konsep dan prinsip dalam teori konstruktivisme Lev Vygotsky dikemukakan oleh Ormrod (2012: 314) bahwa manusia memiliki kemampuan untuk menggunakan fungsi mental mereka untuk meningkatkan pembelajaran, ingatan dan penalaran logis. Menurut pandangan Vygotsky, dasar fungsi mental manusia dibangun secara biologis dan untuk mengembangkan fungsi mental tersebut, manusia memutuhkan peranan masyarakat dan budaya.

Ormrod (2012) menjelaskan lebih lanjut terkait konsep-konsep dalam teori konstruktivisme Lev Vygotsky, menurut Ormrod, Vygotsky mengungkapkan gagasan penting dalam teorinya yaitu: a) Interaksi informal maupun formal antara orang dewasa dan anak akan memberi pemahaman bagi anak tentang bagaimana anak berkembang. b) Setiap budaya memiliki makna dalam upaya meningkatkan kemampuan kognitif anak, kebermaknaan budaya bagi anak bertujuan untuk menuntun anak dalam menjalani kehidupannya secara produktif dan efisien. c) Kemampuan berfikir dan berbahasa berkembang pada awal tahun perkembangan anak. Perkembangan kognitif Vygotsky sangat bergantung pada perkembangan dan penguasaan bahasa. d) Berkembangnya proses mental yang kompleks terjadi setelah anak melakukan aktifitas sosial, dan secara bertahap akan terinternalisasi dalam kognitif anak yang dapat dipergunakan secara bebas. Vygotsky mengemukakan bahwa proses berfikir yang kompleks sangat tergantung pada interaksi sosial anak. Sebagaimana anak mendiskusikan tentang peristiwa, objek dan masalah dengan orang dewasa dan orang lain yang lebih berpengetahuan, maka secara 
bertahap hasil diskusi tersebut akan menjadi bagian dalam struktur berpikir anak. e) Anak akan mampu mengerjakan tugas-tugas yang menantang jika diberi tugas yang lebih menantang dari individu yang kompeten.

Terkait konsep penting dalam teori konstruktivisme Lev Vygotsky, selain Interaksi-interaksi sosial yang berperan dalam membangun pengetahuan anak, Schunk (2012) menfokuskan penjelasannya pada empat konsep utama teori konstruktivisme Vygotsky yang terdiri dari Zone of Proximal Development (ZPD), Scaffolding, serta bahasa dan pemikiran.

\section{Zone of Proximal Development (ZPD)}

Satu konsep yang utama pada teori konstruktivisme Lev Vygotsky adalah Zone of Proximal Development (ZPD). Menurut Vygotsky (1986: 86), ZPD merupakan jarak antara tingkat perkembangan aktual dengan ditentukan oleh pemecahan masalah secara mandiri dan tingkat potensi pembangunan yang ditentukan melalui permasalahan pemecahan di bawah bimbingan orang dewasa atau bekerja sama dengan rekan yang lebih cakap. Maka dapat disintesiskan bahwa ZPD adalah jarak antara tingkat perkembangan sesungguhnya yang ditunjukkan dalam kemampuan pemecahan masalah secara mandiri dan tingkat kemampuan perkembangan potensial yang ditunjukkan dalam kemampuan pemecahan masalah di bawah bimbingan orang dewasa atau teman sebaya yang lebih mampu.

ZPD merupakan istilah vygotsky untuk serangkaian tugas yang sulit dikuasai anak secara mandiri tetapi dapat dipelajari dengan bantuan dari orang lain seperti dari guru atau teman yang lebih mampu. Jadi, batas bawah dari ZPD adalah tingkat sebuah masalah yang mampu di pecahkan oleh anak secara mandiri. Batas atas ZPD adalah tingkat tanggung jawab atau tugas tambahan yang dapat diterima anak dengan bantuan dari seorang instruktur atau guru. Hal ini sejalan dengan pendapat Ormod (2012: 317) bahwa zone of proximal development merupakan konsep wilayah yang menunjukan terjadinya peluang kemampuan anak untuk memahami tugas-tugas sebagai wujud berkembangnya kemampuan kognitif anak. Konsep ZPD dalam teori konstruktivisme Lev Vygotsky memiliki empat tahap dijelaskan oleh Gallimore dan Tharp (dalam Moll, 1990) sebagai berikut:

Tahap I: Tahap pertama menunjukkan bagaimana peserta didik mengembangkan pemahaman tentang bahasa yang sesuai dengan studi mereka dan dasar-dasar topik yang sedang dipelajari dengan mengandalkan orang lain seperti instruktur untuk melakukan suatu tugas.

Tahap II: Pada tahap kedua, pembelajar menggunakan pengetahuan sebelumnya untuk melaksanakan tugas tanpa bimbingan apapun. ZPD terjadi antara tahap pertama dan kedua. Peserta didik berlatih sendiri, yang menyiratkan bahwa mereka melakukan aktivitas tertentu tanpa bantuan. Namun, mereka tidak pada tahap kemampuan sempurna dan terkadang memerlukan beberapa bantuan.

Tahap III: Pada tahap ketiga kinerja dikembangkan. Artinya pada tahap ini peserta didik mencapai tahap kemandirian. Pada tahap ini, seorang peserta didik tidak memerlukan bantuan dari orang dewasa, atau berlatih lebih banyak latihan untuk memperkuat pengetahuan yang sudah ada.

Tahap IV: Pada tahap keempat, peserta didik melakukan deautomatisasi kinerja yang mengarah pada proses pengulangan fungsi, setiap kali menerapkannya pada hasil tahap sebelumnya melalui ZPD.

Pembelajaran seumur hidup oleh setiap individu terdiri dari urutan ZPD yang diatur, 
dari bantuan lain untuk bantuan mandiri yang berulang berulang kali untuk pengembangan kapasitas baru (Moll, 1990). Interpretasi pendekatan sosio-kultural Vygotsky pada perkembangan kognitif adalah bahwa seseorang harus memahami dua prinsip utama karya Vygotsky: Pengetahuan yang Lebih Berpengetahuan (MKO) dan ZPD. MKO mengacu pada seseorang yang memiliki pemahaman yang lebih baik atau tingkat kemampuan yang lebih tinggi daripada pelajar sehubungan dengan tugas, proses, atau konsep tertentu (Galloway, 2001).

ZPD menyiratkan bahwa pada tahap tertentu dalam pengembangan, peserta didik dapat memecahkan berbagai masalah tertentu hanya ketika mereka berinteraksi dengan guru dan bekerjasama dengan rekan sejawat. Begitu aktivitas pemecahan masalah pelajar telah diinternalisasi, masalah yang awalnya dipecahkan di bawah bimbingan dan kerjasama dengan orang lain dapat ditangani secara independen. Vygotsky (1978: 87) mengungkapkan bahwa "apa yang ada di ZPD hari ini akan menjadi tahap perkembangan aktual besok, yaitu, apa yang dapat dilakukan pembelajar dengan bantuan hari ini, dia atau dia akan dapat melakukannya sendiri besok".

Vygotsky percaya bahwa ketika seorang pelajar berada di ZPD untuk tugas tertentu, memberikan bantuan yang tepa, maka hal itu akan memberi kemajuan pelajar untuk mencapai tugas tersebut (Galloway, 2001). Setelah pelajar, dengan bantuan bantuan, tuankan tugas, bantuan kemudian dapat dihapus dan pelajar kemudian dapat menyelesaikan tugasnya sendiri.

\section{Scaffolding}

Konsep lain dalam teori Konstruktivisme Lev Vygotsky adalah Scaffolding. Scaffolding sangat erat kaitannya dengan ZPD yaitu sebuah teknik untuk mengubah level dukungan. Selama sesi pengajaran, orang yang lebih ahli (guru atau peserta didik yang lebih mampu) menyesuaikan jumlah bimbingannya dengan level kinerja murid yang telah dicapai. Ketika tugas yang akan dipelajari murid merupakan tugas yang baru, maka orang yang lebih ahli dapat menggunakan teknik instruksi langsung. Saat kemampuan peserta didik meningkat, maka semakin sedikit bimbingan yang diberikan. Vygotsky menganggap bahwa anak mempunyau konsep yang kaya tetapi tidak sistematis, tidak teratur, dan spontan. Anak akan bertemu dengan konsep yang sistematis dan logis serta rasional yang dimiliki oleh orang yang lebih ahli yang membantunya.

\section{Bahasa dan pemikiran}

Perkembangan manusia terjadi melalui alat-alat kultur (bahasa dan simbol-simbol) yang kemudian diteruskan dari satu orang ke orang lain atau sering disebut dengan transmisi alat-alat kultur (Schunk: 2012: 341). Bahasa adalah alat kultur yang paling penting. Bahasa di dapat dari tuturan sosial, kemudian untuk disimpan dalam tuturan pribadi, dan akhirnya menjadi tuturan tersembunyi (didalam).

Vygotsky mempercayai bahwa bahasa tidak hanya untuk komunikasi sosial, tetapi juga untuk merencanakan, memonitor perilaku mereka dengan caranya sendiri dinamakan "pembicaraan batin" (inner speech) (pembicaraan privat). Menurut Piaget inner speech bersifat egosentris dan tidak dewasa. Tetapi menurut teori Vygotsky inner speech adalah alat penting bagi pemikiran selama masa kanak-kanak (early childhood). Anakanak berkomunikasi dengan orang lain menggunakan bahasa sebelum mereka dapat fokus pada pemikirannya. Anak-anak menggunakan bahasa untuk 
komunikasi dengan dunia luar selama periode agak lama sebelum transisi dari pembicaraan eksternal ke pembicaraan internal (batin). Periode transisi terjadi antara usia 3 sampai 7 tahun dan terkadang anak dalam usia ini sering berbicara sendiri. Setelah beberapa waktu kebiasaan berbicara sendiri dapat hilang dan mereka melakukannya tanpa harus diucapkan. Ketika ini terjadi anak sudah memasukkan pembicaraan egosentris menjadi inner speech, dan pembicaraan batin ini kemudian akan menjadi pemikiran mereka. Teori Vygotsky mengemukakan bahwa anak yang menggunakan inner speech merupakan proses awal menjadi komunikatif secara sosial dan juga menegaskan bahwa seorang anak yang menggunakan inner speech akan lebih kompeten secara sosial daripada anak yang tidak menggunakannya (Santrock. 2013: 63).

Teori Vygotsky mengundang banyak perhatian karena teorinya mengandung pandangan bahwa pengetahuan itu dipengaruhi situasi dan bersifat kolaboratif. Artinya pengetahuan didistribusikan diantara orang dan lingkungan, yang mencakup objek, alat, buku, dan komunitas dimana orang berada. Hal ini menunjukkan bahwa memperoleh pengetahuan dapat dicapai dengan baik melalui interaksi dengan orang lain dalam kegiatan bersama.

\section{Implikasi Teori Konstruktivisme Vygotsky}

Teori konstruktivisme menekankan pada peserta didik sebagai pembelajar aktif, sehingga dalam penerapannya teori konstruktivisme sering disebut sebagai strategi pengajaran yang berpusat pada peserta didik (student-centered instruction). Di ruang kelas yang berpusat pada peserta didik, guru menjadi "pemandu di samping" dan bukan "orang bijaksana di atas panggung", dengan membantu peserta didik menemukan makna mereka sendiri dan bukan mengendalikan semua kegiatan di ruang kelas (Weinberger \& Combs: 2001). Menurut Drake (2012: 273), pendekatan tematik merupakan bentuk strategi pembelajaran yang menggunakan tema melalui penciptaan pembelajaran yang aktif, menarik, dan bermakna. Dikatakan bermakna karena peserta didik akan dapat memahami konsep-konsep melalui pengalaman langsung dan nyata yang menghubungkan antar konsep. Melalui kurikulum 2013, peserta didik akan didorong menjadi insan yang kreatif, produktif, inovatif, dan afektif melalui kompetensi-kompetensi yang berimbang antara spiritual, pengetahuan, sikap, dan psikomotor/keterampilan.

Teori konstruktivisme menekankan pada peserta didik sebagai pembelajar aktif, sehingga dalam penerapannya teori konstruktivisme sering disebut sebagai strategi pengajaran yang berpusat pada peserta didik (student-centered instruction). Di dalam ruang kelas yang berpusat pada peserta didik, guru menjadi "pemandu di samping" dan bukan "orang bijaksana di atas panggung”, dengan membantu peserta didik menemukan makna mereka sendiri dan bukan mengendalikan semua kegiatan di ruang kelas (Weinberger \& Combs: 2001). Menurut Drake (2012: 273), thematic approach is one of the teaching strategy that uses themes toward creating anactive, interest-ing, and meaningful learning. Hal ini sesuai dengan pendekatan tematik merupakan bentuk strategi pembelajaran yang menggunakan tema melalui penciptaan pembelajaran yang aktif, menarik, dan bermakna. Dikatakan bermakna karena peserta didik akan dapat memahami konsepkonsep melalui pengalaman langsung dan nyata yang menghubungkan antar konsep. 
Melalui kurikulum 2013, peserta didik akan didorong menjadi insan yang kreatif, produktif, inovatif, dan afektif melalui kompetensi-kompetensi yang berimbang antara spiritual, pengetahuan, sikap, dan psikomotor/keterampilan.

Menurut Suparno (1997: 65) peran guru dalam pembelajaran konstruktivis adalah sebagai mediator dan fasilitator yang membantu agar proses belajar peserta didik berjalan dengan baik. Fungsi mediator dan fasilitator dapat dijabarkan dalam beberapa tugas sebagai berikut: 1) menyediakan pengalaman belajar yang memungkinkan peserta didik bertanggung jawab dalam membuat rancangan, proses dan penelitian 2) menyediakan atau memberikan kegiatankegiatan yang merangsang keingintahuan peserta didik dan membantu mereka untuk mengekspresikan gagasan-gagasannya dan mengkomunikasikan ide ilmiah mereka (Watts \& Pope, 1989). Menyediakan sarana yang merangsang peserta didik berfikir secara produktif. Menyediakan kesempatan dan pengalaman yang paling mendukung proses belajar peserta didik. Guru harus menyemangati peserta didik. Guru perlu menyediakan pengalaman konflik (Tobin, Tippins \& Gallard: 1994) 3) memonitor, mengevaluasi dan menunjukkan apakah peikiran peserta didik berjalan atau tidak. Guru menunjukkan dan mempertanyakan apakah pengetahuan peserta didik itu berlaku untuk menghadapi persoalan baru yang berkaitan. Guru membantu mengevaluasi hipotesis dan kesimpulan peserta didik.

Hal ini sesuai dengan kurikulum 2013 yang menempatkan guru sebagai fasilitator dalam pembelajaran dan peserta didik sebagai pelaku belajar. Menitik pada pembelajaran konstruktivis yang berorientasi pada peserta didik dalam membangun sendiri pengetahuannya, maka seorang guru harus melihat bahwa peserta didik bukanlah lembaran kertas putih bersih atau sebuah bejana kosong. Hal ini berangkat dari fakta bahwa peserta didik yang berada di tataran kelas yang paling rendahpun telah hidup beberapa tahun dan menemukan suatu cara yang berlaku untuk menghadapi lingkungan hidup mereka. Mereka sudah membawa "pengetahuan awal". Pengetahuan yang mereka punyai adalah dasar untuk membangun pengetahuan selanjutnya. Karena itu, guru perlu mengerti taraf pengetahuan anak (Glasersfeld: 1989).

Apa pun yang dikatakan seorang peserta didik dalam menjawab suatu persoalan adalah jawaban yang masuk akal bagi mereka pada saat itu. Maka dalam hal ini guru sebaiknya tidak langsung menilai bahwa jawaban peserta didik salah, karena bagi peserta didik dinilai salah merupakan suatu yang mengecewakan dan mengganggu sehingga dapat menimbulkan efek negatif bagi peserta didik. Oleh karena itu, sebaiknya guru memberikan jalan kepada peserta didik untuk menginterpretasikan pertanyaannya. Dengan demikian maka dapat menuntun peserta didik untuk memahami kesalahannya sendiri dan dapat menyusun jawabanjawaban yang lebih tepat/baik (Glasersfeld: 1989).

Pembelajaran dari sudut pandang teori konstruktivisme Lev Vygotsky mengarah pada aktivitas pengaturan lingkungan agar terjadi proses belajar, yaitu interaksi antara pembelajar dengan lingkungan belajarnya. Winkel (1996) menyatakan bahwa inti dari pembelajaran konstruktivis adalah penataan lingkungan belajar. Lingkungan belajar berarti tempat dimana si pembelajar dapat berinteraksi, bekerjasama dan mendukung satu sama lain untuk mencapai tujuan pembelajaran dengan menggunakan berbagai sarana dan sumber belajar. Dalam hal ini maka penerapan teori konstruktivisme Lev 
Vygotsky dapat dilakukan dengan menciptakan suasana belajar yang interaktif dengan memanfaatkan sarana dan sumber belajar.

Berdasarkan uraian aplikasi teori konstruktivisme Lev Vygotsky di atas beberapa hal yang perlu ditekankan dalam penerapannya yaitu: 1) pembelajaran harus dimulai dari batas zona bahwah dalam ZPD; 2) penggunaan teknik scaffolding digunakan ketika peserta didik membutuhkan bantuan; 3) memberdayakan teman sebaya sebagai ahli; 4) pembelajaran akan lebih efektif dengan melibatkan komunitas orang belajar.

Model Pembelajaran Tematik dalam Kurikulum 2013

Kurikulum 2013 mempunyai tujuan untuk mempersiapkan insan Indonesia yang memiliki kemampuan hidup sebagai pribadi dan warga negara yang produktif, kreatif, inovatif, dan efektif, serta mampu berkontribusi pada kehidupan bermasyarakat, berbangsa, bernegara dan peradaban dunia (Permendikbud Nomor 66 Tahun 2013). Sedangkan aspek utama pada Kurikulum 2013 yaitu Standar Kompetensi Lulusan (SKL), Kompetensi inti (KI), Kompetensi Dasar (KD), dan indikator yang berbasis scientific approach dan authentic assessment. Kurikulum 2013 juga memiliki beberapa karakteristik yang lebih menekankan pada pencapaian kompetensi sikap, pengetahuan, dan keterampilan.

Menurut Drake (2012: 273), Pendekatan tematik merupakan bentuk strategi pembelajaran yang menggunakan tema melalui penciptaan pembelajaran yang aktif, menarik, dan bermakna. Dikatakan bermakna karena peserta didik akan dapat memahami konsep-konsep melalui pengalaman langsung dan nyata yang menghubungkan antar konsep. Melalui kurikulum 2013, peserta didik akan didorong menjadi insan yang kreatif, produktif, inovatif, dan afektif melalui kompetensi-kompetensi yang berimbang antara spiritual, pengetahuan, sikap, dan psikomotor/keterampilan.

Hal baru yang muncul dari penerapan kurikulum 2013 yaitu model pembelajaran tematik. Pembelajaran tematik yaitu pembelajaran yang menggunakan tema untuk mengaitkan beberapa materi pelajaran sehingga mampu memberikan pengalaman yang bermakna bagi peserta didik (Authentic \& Sekolah, 2013). Pembelajaran tematik lebih menekankan pada keterlibatan peserta didik dalam proses belajar secara aktif dalam proses pembelajaran, sehingga peserta didik dapat memperoleh pengalaman langsung dan terlatih untuk dapat menemukan berbagai pengetahuan yang dipelajarinya (Suyanto, 2013:180).

Menurut beberapa pendapat diatas dapat disimpulkan bahwa kurikulum 2013 adalah kurikulum yang mempunyai tujuan untuk mempersiapkan warga Indonesia yang memiliki kemampuan hidup sebagai pribadi dan warga negara yang produktif, kreatif, inovatif, dan efektif, serta mampu berkontribusi pada kehidupan bermasyarakat, berbangsa, bernegara dan peradaban dunia. Kurikulum 2013 memiliki beberapa karakteristik yang lebih menekankan pada pencapaian kompetensi sikap, pengetahuan, dan keterampilan.

\section{Pelaksanaan Pembelajaran Tematik di}

\section{Sekolah Dasar dalam Pandangan Teori}

\section{Konstruktivisme Vygotsky}

Prinsip pembelajaran pada kurikulum 2013 adalah memadukan antara kempetensi kognitif (pengetahuan), afektif (sikap), dan keterampilan (psikomotor). Ketiga kompetensi memiliki lintasan perolehan yang berbeda (M. Fadlillah, 2014:178). Pendekatan yang digunakan dalam pembelajaran Kurikulum 2013 yaitu 
pendekatan scientific. Pendekatan scientific adalah pendekatan yang dilakukan dengan adanya proses ilmiah dalam pembelajaran (M. Fadlillah, 2014:175). Pendekatan scientific adalah pembelajaran yang dilakukan melalui proses mengamati, menanya, mencoba, menalar, dan mengkomunikasikan. Pada penerapan pendekatan scientific sebaiknya guru memperhatikan beberapa prinsip dalam melaksanakan pembelajarannya. Sesuai dengan permendikbud nomer 22 tahun 2016 yang mengungkapkan beberapa prinsip dalam melaksanakan pembelajaran Kurikulum 2013 yaitu (1) berpusat pada peserta didik; (2) mengembangkan kreativitas peserta didik; (3) menciptakan kondisi yang menyenangkan dan menantang; (4) bermuatan nilai etika, estetika, logika, dan kinestetik; (5) menyediakan pengalaman belajar yang beragam melalui berbagai strategi dan metode pembelajaran yang menyenangkan, kontekstual, efektif, efisien, dan bermakna.

Teori Vygotsky mendukung untuk menciptakan pembelajaran yang sesuai agar peserta didik memperoleh pengalaman langsung secara berkelompok. Selain itu Vygotsky mengemukakan bahwa seorang anak usia Sekolah Dasar sudah mulai dapat memecahkan masalah secara berkelompok, sehingga sebaiknya guru menerapkan metode pembelajaran yang mampu mendukung peserta didik untuk menemukan jawabannya sendiri melalui pengalaman langsung dan dilakukan secara berkelompok.

Dalam teori konstruktivisme Lev Vygotsky dikemukakan bahwa pengetahuan dibangun melalui interaksi sosial, interaksi sosial dapat terjalin pada dua orang atau lebih, sehingga selain kegiatan peer tutoring yang dilakukan oleh dua peserta didik yang saling berinteraksi, belajar dalam kelompok juga sangat memungkinkan untuk membantu peserta didik dalam mengkonstruksi pengetahuannya. Glasersfeld menjelaskan bagaimana pengaruh konstruktivisme terhadap belajar dalam kelompok. Menurutnya, dalam kelompok belajar peserta didik dapat mengungkapkan bagaimana ia melihat persoalan dan apa yang akan dilakukan terhadap persoalan tersebut. Hal ini sesuai dengan pendekatan pembelajaran tematik yaitu scientif.

Langkah-langkah yang dilakukan dalam mengimplementasikan pendekatan scientific yaitu: 1) Mengamati. Dalam kegiatan mengamati, guru membuka kesempatan secara luas dan bervariasi kepada peserta didik untuk melakukan pengamatan melalui kegiatan menyimak, melihat, mendengarkan, dan membaca. 2) Menanya. Ketika kegiatan menanya, guru memberi kesempatan kepada peserta didik untuk bertanya mengenai apa yang sudah dilihat, disimak, didengar, dibaca dan dilihat. 3) Mengumpulkan dan mengasosiasikan. Tindak lanjut dari menanya adalah mencari informasi-informasi dari berbagai sumber yang dapat mendukung pembelajaran pada hari itu. Sumber informasi dapat diperoleh darimana saja dan melalui apasaja. 4) Mengkomunikasikan hasil. Peserta didik melakukan kegiatan menuliskan apa yang mereka temukan dalam kegiatan mencari informasi, mengasosiasikan, dan menentukan pola. Kemudian hasil yang mereka tuliskan akan dipresentasikan di hadapan guru dan teman-temannya yang lain.

\section{Model Pembelajaran Tematik di Sekolah Dasar dalam Pandangan Teori Konstruktivisme Vygotsky}

Model pembelajaran mengacu pada pendekatan pembelajaran yang akan digunakan, termasuk di dalamnya tujuantujuan pengajaran, tahap-tahap dalam 
kegiatan pembelajaran, lingkungan pembelajaran, dan pengelolaan kelas. Tujuan penggunaan model pembelajaran sebagai strategi bagaimana pembelajaran yang dilaksanakan dapat membantu peserta didik mengembangkan dirinya baik berupa informasi, gagasan, keterampilan nilai dan cara-cara berpikir dalam meningkatkan kapasitas berpikir secara jernih, bijaksana dan membangun keterampilan sosial serta komitmen (Joice\& Wells). Model pembelajaran mempunyai empat ciri khusus yaitu: 1) Rasional teoretis logis yang disusun oleh para pencipta atau pengembangnya. Model pembelajaran mempunyai teori berfikir yang masuk akal. Maksudnya para pencipta atau pengembang membuat teori dengan mempertimbangkan teorinya dengan kenyataan sebenarnya serta tidak secara fiktif dalam menciptakan dan mengembangankannya. 2) Landasan pemikiran tentang apa dan bagaimana siswa belajar (tujuan pembelajaran yang akan dicapai). Model pembelajaran mempunyai tujuan yang jelas tentang apa yang akan dicapai, termasuk di dalamnya apa dan bagaimana siswa belajar dengan baik serta cara memecahkan suatu masalah pembelajaran. 3) Tingkah laku mengajar yang diperlukan agar model tersebut dapat dilaksanakan dengan berhasil. Model pembelajaran mempunyai tingkah laku mengajar yang diperlukan sehingga apa yang menjadi cita-cita mengajar selama ini dapat berhasil dalam pelaksanaanya. 4) Lingkungan belajar yang diperlukan agar tujuan pembelajaran itu dapat tercapai. Model pembelajaran mempunyai lingkungan belajar yang kondusif serta nyaman, sehingga suasana belajar dapat menjadi salah satu aspek penunjang apa yang selama ini menjadi tujuan pembelajaran. (Trianto, 2010).
Memilih atau menentukan model pembelajaran sangat dipengaruhi oleh kondisi Kompetensi Dasar (KD), tujuan yang akan dicapai dalam pengajaran, sifat dari materi yang akan diajarkan, dantingkat kemampuan peserta didik. Di samping itu, setiap model pembelajaran mempunyai tahap-tahap (sintaks) yang dapat dilakukan siswa dengan bimbingan guru. Pelaksanaan pembelajaran dengan pendekatan saintifik sebagaimana yang diterapkan pada kurikulum 2013, sebaiknya dipadukan secara sinkron dengan langkah/tahapan kerja (syntax) model pembelajaran.

Kurikulum 2013 menggunakan 3 (tiga) model pembelajaran utama (Permendikbud No. 103 Tahun 2014) yang diharapkan dapat membentuk perilaku saintifik, perilaku sosial serta mengembangkan rasa keingintahuan. Ketiga model tersebut adalah: model Pembelajaran Berbasis Masalah (Problem Based Learning), model Pembelajaran Berbasis Projek (Project Based Learning), dan model Pembelajaran Melalui Penyingkapan/Penemuan (Discovery/Inquiry Learning).

Tidak semua model pembelajaran tepat digunakan untuk semua $\mathrm{KD}$ atau materi pembelajaran. Model pembelajaran tertentu hanya tepat digunakan untuk materi pembelajaran tertentu. Sebaliknya materi pembelajaran tertentu akan dapat berhasil maksimal jika menggunakan model pembelajaran tertentu.

Oleh karenanya guru harus menganalisis rumusan pernyataan setiap KD, apakah cenderung pada pembelajaran penyingkapan (Discovery/Inquiry leraning) atau pada pembelajaran hasil karya (Problem Based Learning dan Project Based Learning). 


\section{KESIMPULAN}

Pembelajaran

tematik adalah pembelajaran yang menggunakan pendekatan scientific yang memberikan kesempatan peserta didik untuk dapat melakukan proses ilmiah yaitu mengamati, menanya, menalar, mencoba, dan mengkomunikasikan. Hal ini sangat sesuai dengan teori belajar Konstruktivisme Vygotsky yaitu setiap individu dapat membangun informasi ataupun pengetahuan secara mandiri melalui interaksi sosial dengan orang lain atau dengan orang yang lebih mampu. Pemberian bantuan kepada peserta didik harus memperhatikan Zone Of Proximal Development (ZPD). Zone of Proximal Development merupakan istilah Vygotsky untuk serangkaian tugas yang sulit dikuasai anak secara mandiri tetapi dapat dipelajari dengan bantuan dari orang lain seperti dari guru atau teman yang lebih mampu. Zone of Proximal Development (ZPD) akan berkaitan erat dengan scaffolding, scaffolding yaitu pemberian bantuan yang semakin lama semakin dikurangi sesuai dengan tingkat penguasaan peserta didik dalam memahami tugas.

Apabila peserta didik sudah mampu untuk melakukan suatu proses belajar secara mandiri maka pemberian bantuan akan dilepas merupakan salah satu prinsip teori Vygotsky yang dapat di terapkan pada pembelajaran tematiksebab peran guru disini lebih dominan sebagai fasilitator dalam proses belajar mengajar. Pembelajaran tematik lebih menghendaki peserta didik untuk bertukar fikiran atau diskusi dengan teman sebaya maupun orang yang lebih mampu untuk berkonsultasi, hal ini sesuai dengan implikasi teori belajar Konstruktivisme Vygotsky yang menghendaki pembelajaran yang menempatkan pembelajaran berorientasi pada student center.

Kurikulum 2013 menggunakan 3 (tiga) model pembelajaran utama (Permendikbud No. 103 Tahun 2014) yang diharapkan dapat membentuk perilaku saintifik, perilaku sosial serta mengembangkan rasa keingintahuan. Ketiga model tersebut adalah: model Pembelajaran Berbasis Masalah (Problem Based Learning), model Pembelajaran Berbasis Projek (Project Based Learning), dan model Pembelajaran Melalui Penyingkapan/Penemuan (Discovery/Inquiry Learning).

\section{DAFTAR RUJUKAN}

Abdurrahman, H., \& Soerjono. (1999). Metode penelitian deskriptif. Jakarta: Rineka Cipta.

Apriani, A., Wangid, M. N., \& Yogyakarta, U. N. (2015). THE EFFECT OF THEMATIC INTEGRATIVE SSP ON THE CHARACTERS OF DISCIPLINE, 3, 12-25

Authentic, D. A. N., \& Sekolah, A. (2013). The analysis of integrative thematic content, scientific approach, and authentic assessment in elementary school textbooks, 1-15.

Borchelt, N. (2007). Cognitive Computer Tools In The Teaching And Learning Of Undergraduate Calculus. International Journal For The Scholarship Of Teaching And Learning, 1(2):1-17.

Drake, S.M. (2012). Creating standards based integrated curriculum: the commom core state standards edition. California. Corwin Press A sage Publication Company.

Galloway, C. M. (2001). Vygotsky's Constructionism. In $M$ Orey (Ed.). Emerging Perspectives On Learning, Teaching, And Technology. Georgia: College of Education University Of Georgia.

Glasersfeld, E. V. (1989). Knowing without Metaphysics: Aspect of The Radical Constructivist Position. Research and Reflexivity: Toward a Cbernetic/Social Constructivist Way of Knowing. London: Sage 
Joyce, B \& Weil. (2009). Model-model Pengajaran. Edisi 8. Terjemahan A.

Fuwaid \& A. Mirza. Yogyakarta: Pustaka Pelajar.

Kemdikbud. (2013). Peraturan Menteri pendidikan Nasional dan Kebudayaan RI No 67 Tahun 2013 tentang standar proses.

M. Fadlillah. (2014). Implementasi Kurikulum 2013 dalam Pembelajaran SD/MI, SMP/MTs, \&SMA/MA. Yogyakarta: ArRuzz.

Ormrod, J. E. (2012). Human Learning. (6th ed.). United State of America: Pearson Education, Inc.

Santrock, J. W. (2013). Psikologi Pendidikan. (2nd ed.). (Terjemahan Tri Wibowo). Jakarta: Kencana Prenada Media Grup. (Edisi asli diterbitkan tahun 2004 oleh McGraw Hill Company, Inc).

Saptono. (2011). Dimensi-dimensi pendidikan karakter. Salatiga: Esensi.

Schunk, D. H. (2012). Learning Theories. (Terjemahann Eva Hamdiah dan Rahmat Fajar). Yogyakarta: Pustaka Pelajar.
Suparno, P. (1997). Filsafat Konstruktivisme dalam Pendidikan. Yogyakarta:

Kanisius Tobin, K., Tippins, D., \& Gallard, A. (1994). Handbook of Research on Science Teaching and Learning. (pp. 45-93). New York: Macmillan Publishing Company

Trianto. 2010. Model Pembelajaran Terpadu, Konsep, Strategi dan Implementasinya dalam KTSP. Jakarta: Bumi Aksara.

Vygotsky, L. S. (1986). Though and Language. (Translate, revised and edited by Alex Kozulin). London: The Massachusetts Institute of Technology. (Edisi asli diterbitkan tahun 1934 oleh lembaga sosial dan ekonomi Moskow)

Wertsch, J. V. (1985). Vygotsky And The Social Formation of Mind. Cambridge, MA: Harvard University Press

Watts \& Pope. (1989). Thinking about Thinking, Learning about Learning: Constructivism in Physics Education. Physics Education,24: 326-331. 